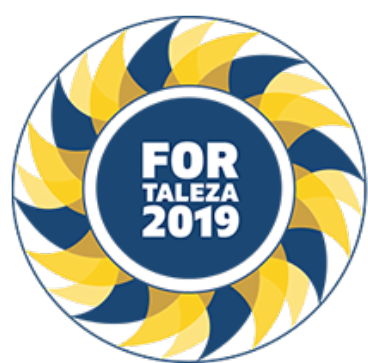

SBR 2019

$36^{\circ}$

CONGRESSO

BRASILEIRO DE

REUMATOLOGIA

CENTRO DE EVENTOS DO CEARÁ O4 A 07 DE SETEMBRO

\title{
METHOTREXATE IN JUVENILE IDIOPATHIC ARTHRITIS: ADVERSE EVENTS
}

THALITA BELATO SOUZA (FACULDADE DE MEDICINA DE BOTUCATU - UNIVERSIDADE ESTADUAL PAULISTA (UNESP), BOTUCATU, SP, Brasil), TACIANA ALBUQUERQUE PEDROSA FERNANDES (HOSPITAL DAS CLÍNICAS DA FACULDADE DE MEDICINA DE BOTUCATU - UNIVERSIDADE ESTADUAL PAULISTA (UNESP), BOTUCATU, SP, Brasil)

\section{BACKGROUND}

Juvenile Idiopathic Arthritis (JIA) is the most common rheumatic disease of childhood with an incidence of 1 case per 1000 children. Methotrexate (MTX) represents fundamental and effective drug in the treatment of JIA. Despite its relevance as a therapy, MTX has important adverse events that may interfere with patient compliance and thus impair treatment. The purpose from this work was evaluate the incidence of adverse events caused by MTX in pediatric subjects with JIA at the Pediatric Rheumatology Service of the Botucatu Medical School - Universidade Estadual Paulista (HC FMB - UNESP).

\section{MATERIALS AND METHODS}

A retrospective study was carried out with the analysis of 74 charts of children who fulfilled ILAR criteria for JIA and who used MTX.

\section{RESULTS}

Seventy-four patients were evaluated, and 39 (52.7\%) presented some type of adverse event during the use of MTX. The most common adverse events were nauseas and vomiting (64.1\%), abdominal pain (35.89\%), elevation of liver enzymes (17.94\%) and neutropenia (10.25\%). No statistical difference was found between adverse events and route of administration, dose, initiation of MTX use, or use of concomitant medications.

\section{CONCLUSION}

The most prevalent adverse events of MTX in our service were gastrointestinal. Despite this, MTX is the disease modifying antirheumatic drug safe in the treatment of JIA, since no serious adverse events were seen with usual dose use. 